\title{
ENZYMATIC PEPTIDE SYNTHESIS. CARBOXYPEPTIDASE Y CATALYZED FORMATION OF PEPTIDE BONDS
}

\author{
by \\ FRED WIDMER and JACK T. JOHANSEN \\ Department of Chemistry, Carlsberg Laboratory, \\ Gamle Carlsberg Vej 10, DK-2500 Copenhagen Valby
}

Keywords: Enzymatic synthesis, peptide synthesis, carboxypeptidase $\mathrm{Y}$

It is demonstrated that carboxypeptidase $Y$ from Saccharomyces cerevisiae can catalyze the formation of peptide bonds using $\mathrm{N}$-acylamino acid esters as substrates and free amino acids or amino acid amides as nucleophiles. The coupling yields observed with free amino acids were max. $60 \%$ for alanine and lysine and they depended strongly on the reaction parameters; viz. $\mathrm{pH}$, temperature and concentration of the amino acids as well as their structures. Importantly, under the conditions of peptide synthesis, the peptide product is not hydrolyzed. Amino acid amides were incorporated in higher yields $(60-95 \%)$ which were less sensitive to the experimental conditions and the structures of this type of nucleophile. The present study suggests that carboxypeptidase $Y$. having a broad specificity for amino acid side chains, may become a general catalyst for enzymatic peptide synthesis in the homogeneous phase.

\section{INTRODUCTION}

The observation of proteinase catalyzed formation of peptide bonds goes back to BERGMANN and Fraenkel-Conrat (2) and Bergmann and FRUTON (3) who showed in 1937 that papain and chymotrypsin could catalyze the coupling of acylamino acids and amino acid anilides. Those early investigations were briefly intensified prior to the evolution of the current concept of in vivo protein synthesis when it was discussed whether proteinases might be involved in that process $(4,20)$. As this possibility was ruled out, general interest in this area of enzymology lessened apart from more limited subjects such as the plastein reaction (6) and the interaction between proteases and protease inhibitors (30).

The application of enzymes in organic synthesis, however, has been under investigation all along (14), and at the present time the use of

Abbreviations: $T L C=$ thin layer chromatography; $H P L C=$ high performance liquid chromatography; TEAP = triethylammonium phosphate buffer; $\mathrm{NaAc}=$ sodium acetate; $\mathrm{HAc}=$ acetic acid. All other abbreviations of amino acids, amino acid derivatives and peptides are according to the guideline of the IUPAC-IUB Commision on Biochemical Nomenclature (for a compliation see ref. 33). 
proteolytic enzymes for peptide synthesis is once more being explored (15-17, 22-26, 29). Two fundamentally different approaches, a thermodynamic and a kinetic one, can be distinguished. Principle features of the thermodynamic approach are the use of a suitable protease to catalyze the establishment of the thermodynamic equilibrium between the reactants and removal of product from the reaction mixture. Thus, Isowa et al. (15-17), Luisi et al. (22, 29) and OKA and MoriHara (24) found that several serine-, thiol- and metalloendoproteases catalyzed the synthesis of peptides from protected but very soluble di-, tri- and tetrapeptides provided the products precipitated from the reaction mixture on account of their solubility being lower than the equilibrium concentration. A displacement of the equilibrium in favor of synthesis was also achieved by working in biphasic aqueous organic phases (19), by tightly binding the product to a suitable reaction component $(30)$, by the addition of high concentrations of polyalcohols (12) and by performing the reaction on a charged matrix (18).

The basis of the kinetic approach to enzymatic peptide synthesis is exemplified in the studies of FASTREZ and Ferscht (7) on the chymotrypsin catalyzed hydrolysis of $\mathrm{N}$-acetyl-L-phenylalanine ethyl ester (Ac-Phe-OEt) in the presence of various amino acid amides. The reaction is shown in Scheme [1] which illustrates that in the presence of a nucleophile $\left(\mathrm{R}-\mathrm{NH}_{2}\right)$ other than water, e.g. an amino acid amide, the acylenzyme intermediate (Ac-Phe-CT) will be subject to aminolysis in addition to hydrolysis. Assuming $\mathrm{k}_{3} \gg \mathrm{k}_{-3}$ and $\mathrm{k}_{4} \gg \mathrm{k}_{-4}$, the ratio of aminolysis to hydrolysis clearly depends on $\mathrm{k}_{4} / \mathrm{k}_{3}$ as well as on the concentration of the nucleophile which is in competition with $55 \mathrm{~m}$ water. Thus, FASTREZ and FERSCHT found that a one molar concentration of alanine amide at $\mathrm{pH} 10$ was sufficient to successfully compete with hydrolysis, resulting in the predominant formation $(>95 \%)$ of $\mathrm{N}$ acyldipeptide amide. A reaction which follows this principle course had earlier been described by Sluyterman and Wijdenes (31) who had observed the papain-catalyzed oligomerization of leucine methyl ester, the latter being donor and nucleophile in the initial coupling step. MORIHARA and ОKA (23-26) have further exploited this principle for enzymatic peptide synthesis. Using chymotrypsin and trypsin, they synthesized a number of peptides from $\mathrm{N}$-acylamino acid esters and amino acid derived nucleophiles and demonstrated that the reaction was purely due to favorable kinetic rate constants, since high yields could be obtained independent of the product's solubility. This represents an inherent advantage over the thermodynamic approach where the solubility requirements generally necessitate the protection of ionizing amino acid side chains just as in conventional peptide synthesis. As further advantages of the kinetic method MoriHara and OKA noted the feasibility of synthesis with relatively small amounts of enzyme and the high speed of the reaction as compared to the thermodynamic procedure. This point is supported by the recent work of QUAST et al. (27) who found that trypsin-catalyzed resynthesis of the reactive site peptide bond, Lys-15, Ala-16, in kallikrein inhibitor was 100 -fold faster for the case where Lys-15 was esterified prior to the coupling experiment.

In summary, it appears that the possibility of developing a general method of enzymatic peptide synthesis is better with the kinetic than

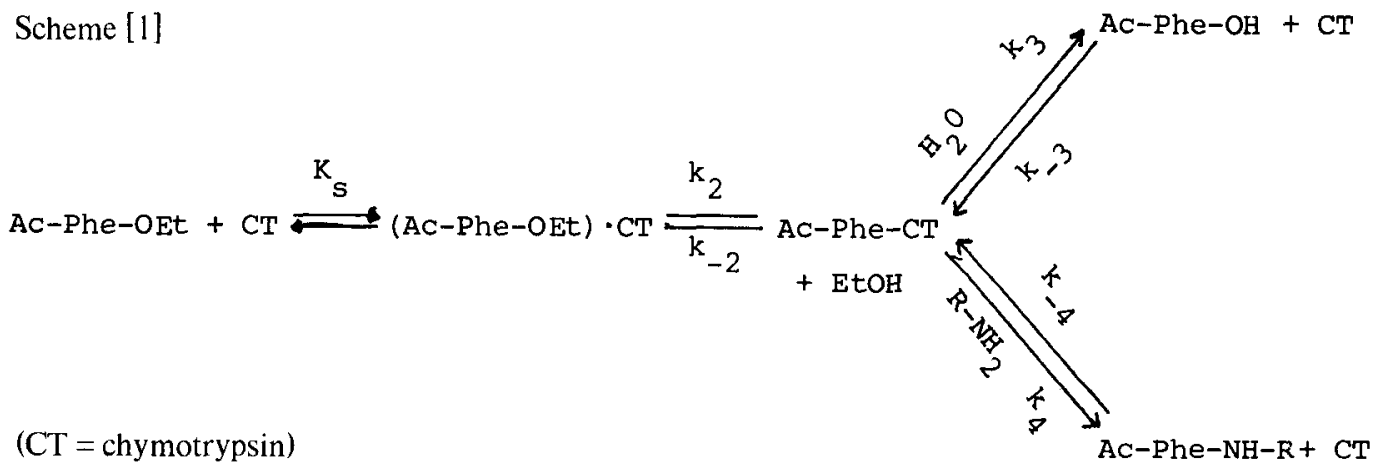


with the thermodynamic approach. However, the narrow specificity properties of the various endoproteases, and the inherent possibility of cleavage of internal peptide bonds when dealing with larger peptides, poses serious limitations for the development of such an approach. On this basis we have concluded that enzymes to be used for a general method of sequential enzymatic peptide synthesis in aqueous phase should minimally meet the following criteria. They should be exoproteases of broad general specificity and form acylenzyme intermediates like serine- and thiolproteases; further, the aminolysis of the intermediate should be possible under conditions where $\mathrm{k}_{-4} \ll \mathrm{k}_{4}$ (cf. Scheme [1]) in order to avoid immediate hydrolysis of the products.

We have found that the carboxypeptidase from bakers' yeast (CPD-Y) at least partially meet these requirements. CPD- $Y$ is a serine enzyme presumably forming an acylenzyme intermediate during the hydrolytic process (1). In addition to its specificity for C-terminal amino acids or esters of $\alpha$-hydroxy acids, CPD-Y also hydrolyses C-terminal methyl-, ethyl- and pnitrophenylesters as well as amides and anilides. Furthermore, CPD-Y exhibits broad specificity, hydrolyzing most substrates independent of the C-terminal amino acid residue (10). Importantly, CPD-Y exhibits activity for alkyl esters up to a high $\mathrm{pH}(\mathrm{pH}>9)$ where its peptidase activity is considerably reduced (11). In view of this situation, an investigation was started with the aim of exploring the potential of this enzyme as a catalyst for peptide synthesis in homogeneous aqueous phase. Some preliminary results are presented in the present report.

\section{MATERIALS AND METHODS}

\subsection{Materials}

Carboxypeptidase $Y$ from bakers' yeast was isolated by the affinity chromatography procedure of JOHANSEN et al. (13) and obtained as a lyophilized powder $(10 \%$ enzyme in sodium citrate). Before use the enzyme was dissolved in water, desalted on Sephadex G-25 fine $(1.5 \times 25$ $\mathrm{cm}$ ) equilibrated and eluted with distilled water. The concentration of the enzyme was determined spectrophotometrically using $\mathrm{E}_{280 \mathrm{~nm}}^{1 \%}=14.8$ (13). A stock solution of $7 \mathrm{mg} \cdot \mathrm{ml}^{-1}(110 \mu \mathrm{M})$ was routinely prepared and stored in aliquots of 250 $500 \mu \mathrm{l}$ at $-21^{\circ} \mathrm{C}$. Benzoylalanine methyl ester was purchased from Bachem, Liestal, Switzerland. Boron trifluoride etherate complex (for synthesis), solvents and reagents (all analytical grade) were from Merck, Darmstadt, West Germany. All amino acids and amino acid amides and their derivatives were from Sigma Chemical Company, St. Louis, USA. Carbobenzoxy-phenylalanine methyl ester (ZPhe-OMe) was prepared according to the procedure of YAMADA et al. (34) and used as a syrup. Phenylalanine hydrazide and alanine hydrazide hydrochloride were prepared from the esters as described (21). The uncorrected melting points were $86-88^{\circ} \mathrm{C}$ (Lit.: $82-83^{\circ} \mathrm{C}(21)$ ) and 182-185 $\mathrm{C}$ (Lit.: $184-185^{\circ} \mathrm{C}(35)$ ), respectively. Asparagine amide dihydrochloride was obtained from aspartic acid via the diethyl ester (9) by classical aminolysis as described (m.p.: 210-214 ${ }^{\circ} \mathrm{C}$, Lit.: $\left.214-215^{\circ} \mathrm{C}(32)\right)$.

\subsection{Enzymatic synthesis of peptides}

The experiments were routinely performed in a Radiometer pH-stat assembly (Model TTT la) in order to have adequate control of the $\mathrm{pH}$-value throughout the experiment. A typical reaction mixture had the following composition: $2 \mathrm{ml}$ of $0.1 \mathrm{M}-\mathrm{KCl}$ with $1 \mathrm{~mm}$-EDTA containing $5.5 \mu \mathrm{M}$ CPD-Y $(0.7 \mathrm{mg}), 50 \mathrm{~mm}$ ester substrate, $5-10 \%$ ethanol or methanol and $0.3-1.0 \mathrm{M}$ of the nucleophile. As a representative example the formation of Bz-Ala-Val-OH from Bz-Ala-OMe and valine is described in detail: $1.5 \mathrm{ml}$ of a $0.7 \mathrm{M}$ stock solution of valine in $0.1 \mathrm{M}-\mathrm{KCl}, \mathrm{pH} 9.5$ with $1 \mathrm{~mm}$-EDTA was placed in the thermostated reaction vessel and the desired $\mathrm{pH}$ adjusted by addition of 100-200 $\mu$ of a concentrated solution of $\mathrm{NaOH}$. This was followed by the addition of $100 \mu \mathrm{Bz}-\mathrm{Ala}-\mathrm{OMe}(1 \mathrm{~m}$ in $96 \%$ ethanol) and the reaction quickly started with $100 \mu$ of the stock solution of CPD-Y. Depending on the ratio of synthesis to hydrolysis prevailing under certain conditions, between 50 and $200 \mu \mathrm{l}$ of $0.25 \mathrm{~m}$ or $0.5 \mathrm{~m}-\mathrm{NaOH}$ were needed to keep the $\mathrm{pH}$ constant throughout the standard reaction time of 10 minutes. During that period aliquots of $25 \mu \mathrm{l}$ were taken, the reaction quenched with $100 \mu \mathrm{l} \mathrm{M}-\mathrm{HCl}$, and the reactant composition analyzed by TLC and/or HPLC. Whenever the 
products were insoluble they were dissolved with ethanol prior to analysis.

\subsection{Determination of product yields}

The yields were determined qualitatively by TLC on Silica Gel $60 \mathrm{~F}_{254}$ (Merck). The solvent system used was $\mathrm{CHCl}_{3} / \mathrm{CH}_{3}\left(\mathrm{CH}_{2}\right)_{3} \mathrm{OH} /$ $\mathrm{CH}_{3} \mathrm{COOH} / \mathrm{H}_{2} \mathrm{O}(11: 5: 2: 1)$ and the spots were visualized by fluorescence quenching for estimation of the reactant composition. Optimal separation was only obtained if the very acidic samples were adjusted to $\mathrm{pH} 9$ with a few drops of $1 \mathrm{M}$ $\mathrm{NaHCO}_{3}, \mathrm{pH} 9.5$ prior to application to the plates.

The reactant compositions were determined quantitatively by reverse-phase HPLC using an RP-8 $10 \mu \mathrm{m}$ (Merck) column and a Hewlett Packard 1084 Chromatograph equipped with a variable wavelength UV detector (Model 79875

A). Separations were achieved using suitable gradients of elution systems from $10 \% \mathrm{CH}_{3} \mathrm{CN}$ in $10 \mathrm{~mm}-\mathrm{NaAc}$, pH 4 to $100 \% \mathrm{CH}_{3} \mathrm{CN}$ or from $10 \mathrm{~mm}-\mathrm{NaAc}, \mathrm{pH} 4$ to $100 \% \mathrm{CH}_{3} \mathrm{CN}$. The latter system was used for compounds such as Bz-Ala-Gly-OH, Bz-Ala-Ala-OH, Bz-Ala-Ser$\mathrm{OH}$ and their respective amides. The flow rate was $3 \mathrm{ml} \cdot \mathrm{min}^{-1}$, the column temperature $47^{\circ} \mathrm{C}$ and the monitoring wavelength $260 \mathrm{~nm}$. The yields were determined on the basis of the molar ratio of the reactants which was obtained from the integrated peak areas of the elution profile; it was assumed that all reactants had identical extinction coefficients.
When ester substrate had remained unused after the standard 10 minutes of reaction (due to inhibition by certain nucleophiles - see section 4) the yields were standardized by setting the two peaks corresponding to the hydrolysis and synthesis products to $100 \%$.

\subsection{Identification of products}

Using thin-layer chromatography the spots were identified by cochromatography of suitable standard compounds. Several products were identified by a combination of HPLC and amino acid analysis. For this purpose, 1 ml-aliquots were taken from the reaction mixture after 10 minutes and quenched with $250 \mu \mathrm{l} 6 \mathrm{M}-\mathrm{HCl}$. The $\mathrm{pH}$ was then adjusted to 4 with $\mathrm{NaOH}$ and the mixture separated by HPLC using Waters equipment including two pumps, a Model 660 Solvent Programmer, a Model U6K Injector, a Model 450 Variable Wavelength Detector combined with a Recorder (Radiometer REC 61) or a Hewlett Packard Recorder/Integrator Model 3380 A. Elution was monitored at a suitable wavelength between $255-280 \mathrm{~nm}$. The chromatography was reverse-phase using a Waters $C-18$ $\mu$-Bondapak column with the elution system TEAP- $20 \%(\mathrm{v} / \mathrm{v})$ TEAP in methanol under suitable gradients and flow rates of 1.5-2.0 $\mathrm{ml} \cdot \mathrm{min}^{-1}$. The TEAP-buffer was prepared according to Rivier (28). In many cases the system 0.1 $\mathrm{M}-\mathrm{HAc}, \mathrm{pH} 3-20 \%(\mathrm{v} / \mathrm{v}) 0.1 \mathrm{M}-\mathrm{HAc}, \mathrm{pH} 3$ in methanol gave also sufficient resolution. All solvents (Merck, zur Analyse) were filtered and

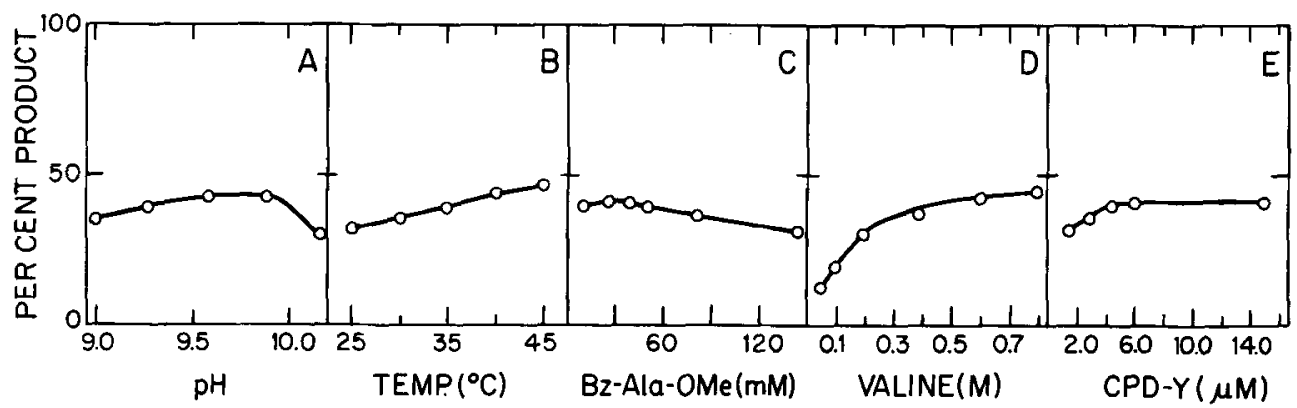

Figure 1. Influence of reaction parameters on the CPD-Y catalyzed synthesis of Bz-Ala-Val-OH from Bz-AlaOMe and valine. The reactions were performed in a Radiometer pH-stat assembly and the yields determined by HPLC as described in section 2. The Figure illustrates the data from five series of experiments. In each series one parameter was varied and four were kept constant. At the constant values valine was $0.6 \mathrm{M}, \mathrm{Bz}$-Ala-OMe $55 \mathrm{~mm}$, CPD-Y $4.5 \mu \mathrm{m}$, the $\mathrm{pH} 9.7$ and the temperature $35^{\circ} \mathrm{C}$. 


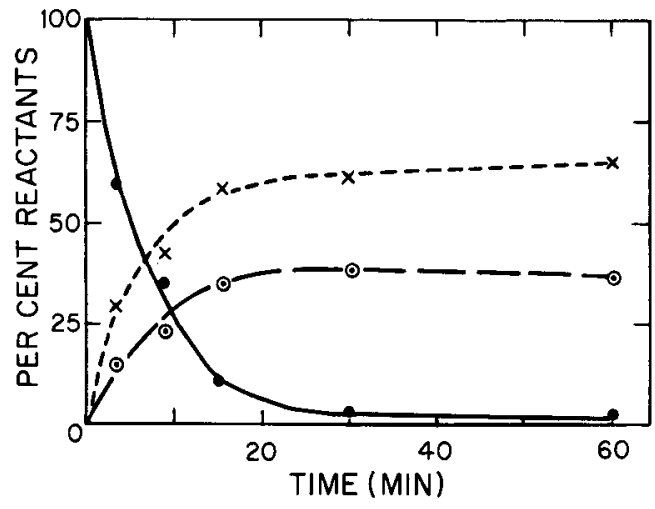

Figure 2. Time course of the CPD-Y catalyzed reaction of valine with Bz-Ala-OMe. Conditions: $0.6 \mathrm{M}$ valine; $55 \mathrm{~mm} \mathrm{Bz}$-Ala-OMe; $4.5 \mu \mathrm{M} \mathrm{CPD}-\mathrm{Y}$; pH 9.7 and $35^{\circ} \mathrm{C}$ - Bz-Ala-OMe; -- Bz-Ala-OH; - - Bz-Ala-Val-OH

degassed using appropriate millipore filters and a Waters vacuum pump.

The effluent containing the $\mathrm{N}$-acyldipeptides was collected manually and taken to dryness by lyophilization or on a Büchi Rotovap at $35-45^{\circ} \mathrm{C}$. Small samples of the residues were hydrolyzed in $6 \mathrm{M}-\mathrm{HCl}$ at $110^{\circ} \mathrm{C}$ in vacuo for 36 h. The evaporated hydrolyzates were then analysed on a Durrum D-500 amino acid analyzer.

\section{RESULTS}

\subsection{Synthesis with free amino acids as nucleophiles}

The effect of $\mathrm{pH}$, temperature and the concentrations of donor, nucleophile and CPD-Y on the yield of the reaction

$$
\begin{array}{r}
\text { Bz-Ala-OMe }+\mathrm{H}-\mathrm{Val}-\mathrm{OH} \underset{\mathrm{Bz}-\mathrm{Ala}-\mathrm{CPal}-\mathrm{Y}}{\longrightarrow} \\
\longrightarrow \mathrm{CH}_{3} \mathrm{OH}
\end{array}
$$

was studied in separate experiments. The results, presented in Figure 1, indicate that the $\mathrm{pH}$-range for optimal yield is rather narrow, extending over $0.5 \mathrm{pH}$-units only (Figure 1A). Further, an increase in the reaction temperature caused an almost linear increase of synthesis on account of relatively less hydrolysis (Figure 1B). However, at temperatures higher than $45^{\circ} \mathrm{C}$, enzyme

\section{Table I}

\begin{tabular}{|c|c|c|c|}
\hline Substrate & Nucleophile (concentration) & Product & Yield \% \\
\hline \multirow{19}{*}{$\mathrm{Bz}$-Ala-OMe } & Glycine $(3.0 \mathrm{M})$ & Bz-Ala-Gly-OH & 12 \\
\hline & Alanine $(1.9 \mathrm{M})$ & Bz-Ala-Ala-OH & 57 \\
\hline & Valine $(0.6 \mathrm{M})$ & Bz-Ala-Val-OH & 40 \\
\hline & Leucine $(0.4 \mathrm{M}) \mathrm{b})$ & Bz-Ala-Leu-OH & 15 \\
\hline & $(0.17 \mathrm{~m})$ & & 24 \\
\hline & Phenylalanine $(0.4 \mathrm{M}) \mathrm{b}$ ) & Bz-Ala-Phe-OH & 3.5 \\
\hline & $(0.16 \mathrm{M})$ & & 27 \\
\hline & Serine $(3.2 \mathrm{~m})$ & Bz-Ala-Ser-OH & 2.5 \\
\hline & Threonine $(0.7 \mathrm{~m})$ & Bz-Ala-Thr-OH & 24 \\
\hline & $(0.35 \mathrm{M})$ & & 15 \\
\hline & Methinonine $(0.6 \mathrm{M})$ & Bz-Ala-Met-OH & 46 \\
\hline & $(0.3 \mathrm{M})$ & & 26 \\
\hline & Lysine $(1.5 \mathrm{M})$ & Bz-Ala-Lys-OH & 56 \\
\hline & $\operatorname{Arginine}(0.8 \mathrm{~m})$ & Bz-Ala-Arg-OH & 26 \\
\hline & $(0.4 \mathrm{M})$ & & 19 \\
\hline & Aspartic acid $(1.0 \mathrm{M})$ & Bz-Ala-Asp-OH & 0 \\
\hline & Asparagine $(0.6 \mathrm{M})$ & Bz-Ala-Asn-OH & 5 \\
\hline & Glutamic acid (1.2 $\mathrm{M})$ & Bz-Ala-Glu-OH & 0 \\
\hline & Glutamic- $\gamma$-methyl ester $(1.0 \mathrm{M})$ & Bz-Ala-Glu(OMe)-OH & 5 \\
\hline \multirow{2}{*}{ Z-Phe-OMe } & Valine $(0.6 \mathrm{~m})$ & Z-Phe-Val-OH & 6 \\
\hline & Lysine $(3.0 \mathrm{M})$ & Z-Phe-Lys-OH & 60 \\
\hline
\end{tabular}

Carboxypeptidase-Y catalyzed synthesis of peptides with amino acids as nucleophiles ${ }^{\text {a). }}$

a) Experiments were performed in a Radiometer $\mathrm{pH}$-stat assembly and the yields determined by HPLC (cf. section 2). The conditions were: $55 \mathrm{~mm} \mathrm{Bz}-\mathrm{Ala}-\mathrm{OMe} ; 4.5 \mu \mathrm{M} \mathrm{CPD}-\mathrm{Y} ; \mathrm{pH} 9.7$ and $35^{\circ} \mathrm{C}$.

b) These solutions contained $20 \%$ dimethylformanide. 
inactivation and non-enzymatic ester hydrolysis became prohibitive. At lower temperatures, and $\mathrm{pH}$-values up to 10.0 , the non-enzymatic hydrolysis was found to be negligible within the 10 minutes standard reaction time; it did become significant, however, when the enzymatic reaction rate was inhibited and called for reaction times up to $2-5$ hours.

While yields of Bz-Ala-Val-OH increased with higher nucleophile concentration (Figure ID), the reverse was the case for the relationship between the yield and the concentration of the donor, viz. Bz-Ala-OMe (Figure IC). The latter observation, taken together with the dependence of the yield on high enzyme concentration (Figure IE), suggests an optimal ratio of the donor/enzyme concentrations.

The time-course of a typical reaction under close to optimal conditions is illustrated in Figure 2. In the presence of $0.5 \mathrm{~m}$ valine, the substrate Bz-Ala-OMe is rapidly (within 20 minutes) converted to $38 \% \mathrm{Bz}-\mathrm{Ala}-\mathrm{Val}-\mathrm{OH}$ and $62 \% \mathrm{Bz}-\mathrm{Ala}-\mathrm{OH}$. The figure further shows that the dipeptide is not hydrolyzed at $\mathrm{pH} 9.7$ in the presence of the excess valine. However, if the $\mathrm{pH}$ was adjusted to 5-8, all Bz-Ala-Val-OH was hydrolyzed within seconds. This selective behaviour of $\mathrm{CPD}-\mathrm{Y}$ at high $\mathrm{pH}$ is an important property for its usefulness in peptide synthesis. Working under the experimental conditions optimal for valine, the yields of dipeptide formation between $\mathrm{Bz}-\mathrm{Ala}-\mathrm{OMe}$, as well as Z-

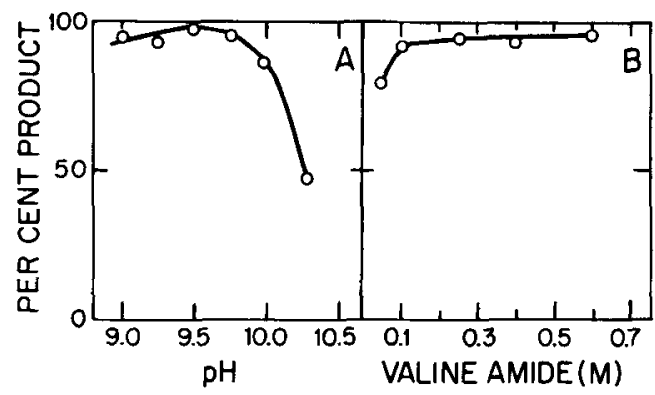

Figure 3. Dependence of the CPD-Y catalyzed synthesis of $\mathrm{Bz}-\mathrm{Ala}-\mathrm{Val}-\mathrm{NH}_{2}$ on $\mathrm{pH}$ and nucleophile concentration. Reactions were performed as described in section 2. The insoluble product was dissolved with ethanol prior to determination of the yield by HPLC. The constant parameters were: $0.6 \mathrm{M}$ valine amide; 55 mм Bz-Ala-OMe; $4.5 \mu \mathrm{M}$ CPD-Y; pH 9.7 and $35^{\circ} \mathrm{C}$.

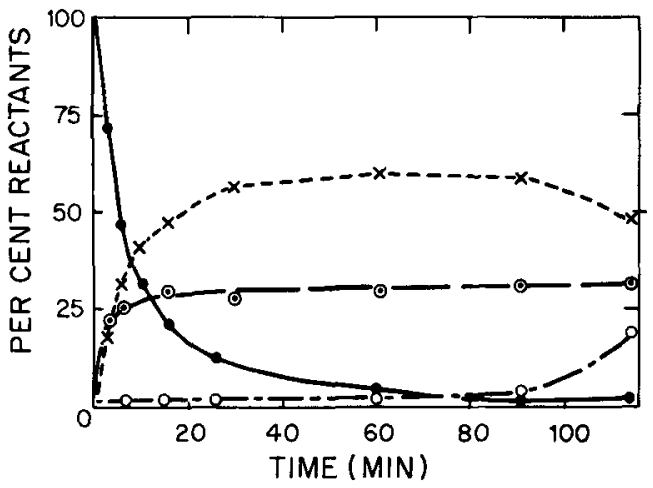

Figure 4. Time-course of the CPD-Y catalyzed reaction of leucine amide with $\mathrm{Bz}-\mathrm{Ala}-\mathrm{OMe}$. The conditions were: $0.5 \mathrm{M}$ leucine amide; $50 \mathrm{~mm} \mathrm{Bz}$ Ala-OMe; $6 \mu \mathrm{M}$ CPD-Y; pH 9.8 and $35^{\circ} \mathrm{C}$. - BzAla-OMe; - - - Bz-Ala-OH; .... Bz-Ala-Leu$\mathrm{NH}_{2} ;---\mathrm{Bz}$-Ala-Leu-OH.

Phe-OMe, and many different amino acids were determined. From the results summarized in Table I it is evident that the extent of synthesis depends strongly on the nature of the amino acid. In addition to this, it appears that there is no simple correlation between high yield and highest possible amino acid concentration; this observation will be further discussed in section 4.

\subsection{Synthesis with amino acid amides and -hydrazides as nucleophiles}

Using valine amide in the model reaction [3]

$$
\text { Bz-Ala-OMe }+\mathrm{H}-\mathrm{Val}-\mathrm{NH}_{2} \underset{\text { Bz-Ala-Val- }}{\stackrel{\mathrm{CPD}-\mathrm{Y}}{\longrightarrow}} \mathrm{NH}_{2}+\mathrm{CH}_{3} \mathrm{OH}
$$

it was found (Figure 3) that the yield of CPD-Y catalyzed dipeptide amide formation was much higher than the one obtained with free valine. Thus, under optimal conditions, $98 \% \mathrm{Bz}$-AlaVal- $\mathrm{NH}_{2}$ was formed as a precipitate; this compares with $42 \%$ for the soluble Bz-Ala-Val$\mathrm{OH}$.

As a further contrast to the situation with valine it was noticed with valine amide that the extent of synthesis was almost insensitive to the nucleophile concentration, at least at a concentration equimolar to or higher than the one of the donor $\mathrm{Bz}$-Ala-OMe $(50 \mathrm{~mm})$. In Figure 3 it is also shown that the effective $\mathrm{pH}$-range for valine amide is extended down to $\mathrm{pH} 9.0$, while a sharp 
Table II

Carboxypeptidase-Y catalyzed synthesis of peptides with amino acid amides and amino acid hydrazides as nucleophiles ${ }^{\mathrm{a}}$ ).

\begin{tabular}{|c|c|c|c|}
\hline Substrate & Nucleophile (concentration) & Product & Yield \% \\
\hline \multirow[t]{9}{*}{ Bz-Ala-OMe } & Glycine amide $(0.3 \mathrm{M})$ & Bz-Ala-Gly-NH ${ }_{2}$ & 90 \\
\hline & Serine amide $(0.3 \mathrm{M})$ & $\mathrm{Bz}-\mathrm{Ala}-\mathrm{Ser}-\mathrm{NH}_{2}$ & 90 \\
\hline & Valine amide $(0.4 \mathrm{M})$ & $\mathrm{Bz}-\mathrm{Ala}-\mathrm{Val}-\mathrm{NH}_{2}$ & $95 b)$ \\
\hline & Leucine amide $(0.3 \mathrm{M})$ & Bz-Ala-Leu- $\mathrm{NH}_{2}$ & 70 \\
\hline & Methionine amide $(0.6 \mathrm{M})$ & Bz-Ala-Met- $-\mathrm{NH}_{2}$ & 50 \\
\hline & Phenylalanine amide $(0.3 \mathrm{M})$ & $\mathrm{Bz}-\mathrm{Ala}-\mathrm{Phe}-\mathrm{NH}_{2}$ & 56 \\
\hline & Tyrosine amide $(0.6 \mathrm{M})$ & $\mathrm{Bz}-\mathrm{Ala}-\mathrm{Tyr}-\mathrm{NH}_{2}$ & 58 \\
\hline & Asparagine amide $(0.3 \mathrm{M})$ & $\mathrm{Bz}-\mathrm{Ala}-\mathrm{Asn}-\mathrm{NH}_{2}$ & 80 \\
\hline & Proline amide $(0.3 \mathrm{M})$ & Bz-Ala-Pro-NH ${ }_{2}$ & 0 \\
\hline Z-Phe-OMe & Valine amide $(0.5 \mathrm{M})$ & Z-Phe-Val- $\mathrm{NH}_{2}$ & 97b) \\
\hline \multirow[t]{2}{*}{$\mathrm{Bz}$-Ala-OMe } & Alanine hydrazide $(0.6 \mathrm{M})$ & $\mathrm{Bz}$-Ala-Ala- $\mathrm{NHNH}_{2}$ & 37 \\
\hline & Phenylalanine hydrazide $(0.3 \mathrm{M})$ & Bz-Ala-Phe-NHNH 2 & $80 \mathrm{~b})$ \\
\hline
\end{tabular}

a) Experiments were performed as described in Section 2 using the following conditions: $55 \mathrm{~mm} \mathrm{Bz}$-Ala-OMe; $4.5 \mu \mathrm{M}$ CPD-Y; $\mathrm{pH} 9.6$ and $35^{\circ} \mathrm{C}$.

b) Product precipitated.

upper cut-off at $\mathrm{pH}>9.8$ is maintained.

The time-course of the CPD-Y catalyzed reaction of leucine amide with Bz-Ala-OMe is presented in Figure 4. The donor ester was converted to approx. $55 \%$ Bz-Ala-Leu- $\mathrm{NH}_{2}$ and $40 \%$ Bz-Ala-OH within 50 minutes. Following an sinduction « period after most Bz-Ala-OMe had been used up, the dipeptide amide, Bz-AlaLeu- $\mathrm{NH}_{2}$, was slowly hydrolyzed to Bz-Ala-Leu$\mathrm{OH}$, which was not itself converted to Bz-Ala$\mathrm{OH}$ and leucine.

In Table II the yields obtained for the synthesis of dipeptide amides and two dipeptide hydrazides are summarized. Apart from proline amide which was not incorporated at all it is seen that, with the exception of alanine hydrazide, each of these nucleophiles gives higher yields than the corresponding free amino acids. Exceptionally high peptide bond formation (95\%) is observed for two cases where the product was insoluble under the conditions of the experiments, viz. Bz-Ala-Val-NH ${ }_{2}$ and Z-Phe-Val$\mathrm{NH}_{2}$. However, for two of the soluble peptides, namely Bz-Ala-Gly- $\mathrm{NH}_{2}$ and Bz-Ala-Ser- $\mathrm{NH}_{2}$, a similarly high degree of synthesis occurred, while for the other amides the yields ranged between $50 \%$ for methionine amide and $80 \%$ for asparagine amide.
The extent of peptide bond formation with alanine hydrazide was $37 \%$ while phenylalanine hydrazide, giving rise to an insoluble product, was incorporated to $80 \%$.

\section{DISCUSSION}

The limited data so far obtained indicate that CPD-Y is capable of synthesizing peptide bonds using N-blocked amino acid methyl esters as substrates and free amino acids, amino acid amides and -hydrazides as nucleophiles. With free amino acids the yields were found to depend critically on the $\mathrm{pH}$ and the structure and the concentration of the acids whereas the substrate or enzyme concentration per se did not affect the yield to the same extent. The fact that the ratio of synthesis over hydrolysis was at all dependent on the enzyme concentration is indeed surprising since the rates of both these processes depend similarly on the level of the catalyst. The lesser extent of synthesis at low levels of CPD-Y is most likely due to enhanced nonenzymatic hydrolysis of the substrate Bz-Ala-OMe because it is used up more slowly and thus exposed to the high $\mathrm{pH}$ of the reaction media for a longer period of time. Similarly, a higher molarity of substrate, without a concomitant raise of the 
enzyme concentration, will result in a higher rate of nonenzymatic hydrolysis.

It appears that certain amino acids by virtue of their inhibitory action at high concentrations may similarly enhance a loss of substrate by nonenzymatic hydrolysis. For example, while higher nucleophile concentration generally resulted in a higher yield of peptide bond formation as expected according to Scheme [1] - it was observed with valine that the curve flattened out at about $0.5 \mathrm{M}$ (Figure ID). Furthermore, for the strongly hydrophobic amino acids leucine and phenylalanine a level seems to exist above which there is not only a levelling off of the synthesis to hydrolysis ratio, but an actual shift towards hydrolysis. However, because the rates of both hydrolysis and synthesis were observed to be strongly inhibited by saturating concentration levels of these amino acids, it could be reasoned that the shift towards hydrolysis is only apparent, i.e. that it is not in fact due to a relatively higher degree of enzymatic hydrolysis but rather due to more pronounced nonenzymatic hydrolysis. On the other hand, the inhibitory binding mode of these amino acids might be such that aminolysis of the acyl-enzyme by these amino acids might be more strongly affected than its hydrolysis by water.

Apart from the concentration of the amino acids, their structure crucially determined the yields obtainable. From the data presented, it can be generalized that hydrophobic amino acids and those carrying a positively charged side-chain are well incorporated whereas the small glycine, and those amino acids whose side chains carry either a carboxylic-, hydroxylic-, or amide function are poorly incorporated. One is lead to assume that the balance of attractive and repulsive forces operational between the active site region of the enzyme and the amino acid is unfavorable for those amino acids belonging to the latter group. It is of interest here that FINK and BENDER (8), in a quantitative study of the effects of added nucleophiles on papain-catalyzed hydrolysis of esters, made similar observations pertaining to the effect of the concentration and structure of the nucleophile on the rate of disappearance of the ester substrate.

As mentioned in section 3, the $\mathrm{pH}$-value of the reaction is of utmost importance for successful synthesis with amino acids as nucleophiles. At $25^{\circ} \mathrm{C}$, the average $\mathrm{pK}_{\mathrm{a}}$ of the $\alpha$-amino group of the common amino acids is about 9.6 (5). The effective nucleophile concentration is given by the molarity of unprotonated $\alpha$-amino groups and thus, the most suitable $\mathrm{pH}$ for the coupling experiment would be approx. $\mathrm{pH} 10$ or higher. However, such a pH represents the upper limit with regard to enzyme stability, enzyme binding properties and rate of nonenzymatic substrate hydrolysis. It was indeed observed that the coupling yield fell drastically off at $\mathrm{pH}>9.8$ (Figure 1A) using Bz-Ala-OMe as the substrate. Besides the fact that alkyl esters like Bz-AlaOMe are substrates for CPD-Y up to $\mathrm{pH} 10$, the temperature dependence of the heat of ionization provided a key to successful coupling of valine to $\mathrm{Bz}-\mathrm{Ala}-\mathrm{OMe}$. An increase in temperature of $10^{\circ} \mathrm{C}$ leads to an average decrease of the $\mathrm{pK}_{\mathrm{a}}$ of the $\alpha$-amino groups of amino acids of approx. $0.3 \mathrm{pH}$-units (5); this change was sufficient to raise the yield of synthesis with valine (Figure IB) and other amino acids (Table I) to acceptable levels.

For amino acid amides as nucleophiles the situation appears to be quite different. The yields were generally high and quite insensitive to the concentration and the structure of the amide. Furthermore, as the average $\mathrm{pK}_{\mathrm{a}}$ of the $\alpha$-amino group of amino acid amides is approx. 8.2 (5), it is possible to employ a much higher effective amine concentration even at $\mathrm{pH} 8.8$ to 9.2. Thus, it is not necessary to resort to elevated temperatures. However, the higher yields observed with the amides cannot be entirely due to their lower $\mathrm{pK}_{\mathrm{a}}$-values. Asparagine amide, for example, was incorporated to $80 \%$ while asparagine, although it has a much lower $\mathrm{pK}_{\mathrm{a}}(8.8)$ than aspartic acid (9.6), was not incorporated even under favorable conditions of $\mathrm{pH}$ and temperature (Tables I and II). Further evidence that there exists a fundamental difference in the mode of interaction of amino acids and amino acid amides with the acyl-enzyme intermediate stems from the observation that leucine- and phenylalanine amide, although being inhibitors of ester acylation, still reacted with $\mathrm{Ba}-\mathrm{Ala}-\mathrm{OMe}$ forming a peptide bond in high yield. This is in contrast to leucine and phenylalanine where inhibition was accompanied by a decreased yield. It could be argued that the high yields obtained with the two amides were due to the inherently lower solubility of 
peptide amides as compared to free peptides. However, both Bz-Ala-Leu- $\mathrm{NH}_{2}$ and Bz-Ala$\mathrm{Phe}-\mathrm{NH}_{2}$ were soluble under the conditions of these experiments as was the case with Bz-AlaLeu-OH and Bz-Ala-Phe-OH. Thus, a thermodynamic type synthesis between Bz-Ala-OH, derived from enzymatic and nonenzymatic hydrolysis, and the amides can be ruled out (synthesis by that mechanism also appears to require higher enzyme concentrations and to proceed more slowly $(15-17,22,24,29))$.

In conclusion, it appears that CPD-Y can catalyse the synthesis of a variety of peptides using either free amino acids, amino acid amides or amino acid hydrazides as nucleophiles. Current work is concerned with the extension of this method to the sequential synthesis of longer peptides as well as with its application to the semisynthesis of $\mathrm{C}$-terminal modified peptides and proteins.

\section{ACKNOWLEDGEMENT}

We are indebted to Professor M. Ottesen for advice and discussions and for critically revising the manuscript. F. WIDMER would like to gratefully acknowledge a Postdoctoral Fellowship from the Carlsberg Laboratory and to thank the members of the Department of Chemistry for pleasant cooperation. In particular, we are grateful to Drs. Brian MarTin and Ib Svendsen for help with HPLC, to BODIL CORNELIUSSEN for amino acid analyses and to THORKILD BeENFELDT and EDITH Floistrup for providing us with purified CPD-Y.

\section{REFERENCES}

1. Auld D. S.: Direct Observation of Transient ES Complexes: Implications to Enzyme Mechanisms. In: Bioorganic Chemistry. E. E. van Tamelen, ed., Academic Press, New York, Vol. $1, \mathrm{pp} 1-12$ (1977)

2. Bergmann M. \& H. Fraenkel-Conrat: The role of specificity in the enzymatic synthesis of proteins. J. Biol. Chem. 119, 707-720 (1937)

3. Bergmann M. \& J. S. Fruton: Some synthetic and hydrolytic experiments with chymotrypsin. J. Biol. Chem. 124, 321-329 (1938)

4. BorsooK H.: Peptide Bond Formation. In: Advances in Protein Chemistry. M. L. Anson, K. Bailey and J. T. Edsall, eds., Academic Press,
New York, Vol. 8, pp. 127-174 (1953)

5. Cohn E. J. \& J. T. Edsall: Proteins, Amino Acids and Peptides. Reinhold, New York (1943)

6. Determann H.: Peptidsynthesen mit Hilfe von Proteolytischen Enzymen (Plasteinreaktion). In: Peptides, L. Zervas, ed., Pergamon Press, Oxford, pp. 89-98 (1966)

7. Fastrez, J. \& A. R. Ferscht: Demonstration of the acyl-enzyme mechanism for the hydrolysis of peptides and anilides by chymotrypsin. Biochemistry 12, 2025-2034 (1973)

8. Fink A. L. \& M. L. Bender: Binding sites for substrate leaving groups and added nucleophiles in papain-catalyzed hydrolyses. Biochemistry 8 , 5109-5118 (1969)

9. FisCHER E.: Ueber die Ester der Aminosäuren. Chem. Ber. 34, 433-454 (1901)

10. HAYASHI R.: Carboxypeptidase Y. In: Methods in Enzymology. L. Lorand, ed., Academic Press, New York, Vol. 45, pp. 568-587 (1976)

11. Hayashi R., Y. Bai \& T. Hata: Kinetic studies of carboxypeptidase $Y$. I. Kinetic parameters for the hydrolysis of synthetic substrates. J. Biochem. 77, 69-79 (1975)

12. Homandberg, G. A., J. A. Mattis \& M. Laskowski Jr.: Synthesis of peptide bonds by proteinases: Addition of organic cosolvents shifts peptide bond equilibria toward synthesis. Biochemistry 17, 5220-5227 (1978)

13. Johansen, J. T., K. Breddam \& M. Ottesen: Isolation of carboxypeptidase $\mathrm{Y}$ by affinity chromatography. Carlsberg Res. Commun. 41. 1-14 (1976)

14. Jones J. B., C. J. Sih \& D. Perlman, eds.: Applications of Biochemical Systems in Organic Chemistry. In: Techniques in Chemistry. A Weissberger, ed., John Wiley, New York, Vol. X, 1976

15. Isowa Y., M. Ohmori, T. Ichikawa, H. Kurita, M. SATO \& K. MORI: The synthesis of peptides by means of proteolytic enzymes. Bull. Chem. Soc. Japan 50, 2762-2765 (1977)

16. Isowa Y., M. Ohmori, M. Sato \& K. Morı: The enzymatic synthesis of protected valine-5 angiotensin II amide-1. Bull. Chem. Soc. Japan 50. 2766-2772 (1977)

17. Isowa Y., T. Ichikawa \& M. Ohmori: Peptide synthesis with proteinases. Fragment condensation of ZLeuGlnGlyOH or ZGInGlyOH with HLeuValNH ${ }_{2}$ using metalloproteinases. Bull. Chem. Soc. Japan 51, 271-276 (1978)

18. KaPUNE A. \& V. Kasche: Kinetically controlled equilibria: The perturbation of hydrolysis of equilibria in reactions catalyzed by $\alpha$-chymotrypsin immobilized on charged supports. Biochem. Biophys. Res. Commun. 80, 955-962 (1978) 
19. Klibanov A. M., G. P. Samokhin, K. Martinek \& J. V. BEREZIN: A new approach to preparative enzymatic synthesis. Biotech. Bioeng. 19, 13511361 (1977)

20. Linderstrom-Lang K.: Biological Synthesis of Proteins. In: Kaj Linderstrøm-Lang, Selected Papers. Academic Press, New York pp. 448-471 (1962)

21. Losse G., H.-J, Hebel \& C. Käsiner: Racematspaltung von Aminosäureamiden und hydraziden. J. Prak. Chemie, 4. Reihe, Band 8, 345-350 (1959)

22. Luisi P. L., R. Saltman, D. Vlach \& R. Guarnaccia: Co-oligopeptides of glycine and aromatic amino acids with variable distance between the aromatic residues. VIII. Enzymatic synthesis of N-protected dipeptide esters. J. Mol. Catalysis 2, 133-138 (1977)

23. Morihara K. \& T. OKa: $a$-chymotrypsin as the catalyst for peptide synthesis. Biochem. J. 163, $531-542(1977)$

24. OKa T. \& K. Morihara: Peptide bond synthesis catalyzed by $\alpha$-chymotrypsin. J. Biochem. 84 , 1277-1283 (1978)

25. OKa T \& K. Morihara: Trypsin as a catalyst for peptide synthesis. J. Biochem. 82, 1055-1062 (1977)

26. OKA T. \& K. Morihara: Protease as a catalyst for peptide synthesis: Synthesis in the absence of product precipitation. Symp. on Peptide Chemistry in Japan, Osaka, pp. 79-84 (1977)

27. Quast U., J. Engel, E. Steffen, H. Tschesche \& S. KUPFER: Stopped-flow kinetic of the resynthesis of the reactive site peptide bond in kallikrein inhibitor (Kunitz) by $\beta$-trypsin. Biochemistry 17, 1675-1682(1978)
28. Rivier J. E.: Use of trialkyl ammonium phosphate (TAAP) buffers in reverse phase HPLC for high resolution and high recovery of peptides and proteins. J. Liq. Chrom. 1, 343366 (1978)

29. Saltman R., D. Vlach \& P. L. Luisi: Cooligopeptides of aromatic amino acids and glycine with variable distance between the aromatic residues. VII. Enzymatic synthesis of $\mathrm{N}$-protected peptide amides. Biopolymers 16, 631-638 (1977)

30. Sealock R. W. \& M. Laskowski Jr.: Enzymatic replacement of the arginyl by a lysyl residue in the reactive site of soybean trypsin inhibitor. Biochemistry 8, 3703-3710 (1969)

31. Sluyterman L. A. \& J. Wijdenes: Sigmoidal progress curves in the polymerization of leucine methyl ester catalyzed by papain. Biochim. Biophys. Acta 289, 195-202 (1972)

32. Smith E. L. \& D. J. Spackman: Leucine aminopeptidase $V$. Activation specificity and mechanism of action. J. Biol. Chem. 212, 271299 (1955)

33. Wünsch E.: Synthese von Peptiden. In: HoubenWeyl, Methoden der Organischen Chemie. E. Müller, ed., Thieme Verlag. Stuttgart, Vol. 15/1, pp. 1-27 (1974)

34. Yamada T., N. Isono, A. Inui, T. Miyazama, S. Kuwata \& H. Watanabe: Esterification of $\mathrm{N}$-(benzyloxycarbonyl) amino acids and amino acids using $\mathrm{BF}_{3}$-etherate as catalyst. Bull. Chem. Soc. Japan 51, 1897-1898 (1978)

35. Zeller E. A., L. A. Blanksma \& J. A. Carbon: Ueber die Wirkung von optisch aktiven Hydraziden auf die Diaminoxydase. Helv. Chim. Acta. $40,257-260$ (1957) 